\title{
The Influence of Online Attention on Governance Behaviors of Minority Shareholders
}

\author{
Xixi Hu \\ Zhongnan University of Economics and Law \\ Wuhan, China \\ Southwest University \\ Chongqing, China
}

\author{
Yongxiang Zhu \\ Zhongnan University of Economics and Law \\ Wuhan, China \\ Southwest University \\ Chongqing, China
}

\author{
Yong Du \\ Southwest University \\ Chongqing, China
}

\begin{abstract}
Internet has been popularized increasingly. As a newly rising governance body that is minority shareholders comes into being, this article studies the impact of investors' online attention on their governance behaviors. It turns out that the investors' online attentions will significantly increase the governance behaviors of voting by hand and voting with feet, yet the preference to the two will vary with the attentions, namely when it gets more attentions, the preference to voting by hand will increase, otherwise, the preference to voting with feet will increase. It proves that the indifferent attitude of minority shareholders can be changed in the internet environment. This article provides new empirical evidence for minority shareholders to participate in the corporate governance, and give clear policy support to China Securities Regulatory Commission to improve online voting and companies to optimize the corporate governance.
\end{abstract}

Keywords—online attention; minority shareholders, governance behavior

\section{INTRODUCTION}

Minority investors are important participants in listed companies and the stock market. How to protect interests of the group has attracted eyeballs of academic field and supervisors. Due to the existence of double principal-agent problem, the interests of minority shareholders may be embezzled by corporate staff (such as managers or majority shareholders)[1,2], which will not only discourage investors but also impede the normal development of the stock market in the country. In the traditional corporate governance, due to high costs of governance, minority shareholders mostly are indifferent to the corporate governance, that is, a free-riding pattern is adopted against the corporate decision-making and the interests embezzled by corporate insiders [4][5], which

This article is supported by the Fundamental Research Funds for the Central Universities (SWU1609153; SWU1509506), Chongqing Social

Science Planning Fund Project (2016QNSH17), and

National Natural Science Foundation of China (71572153) further weakens the corporate governance. In recent years, Chinese authorities have paid high attentions to the phenomenon, and released a series of measures to protect the benefits of minority investors.

With the rapid development of Internet, diverse media has provide easy ways to access corporate information, which has become important information sources that influence investors[6]. Traditional corporate governance has also changed a lot due to huge changes of Internet-based information environment--- minority shareholders come into governance body, the costs of corporate governance is lowered greatly, new governance measures start to rise, the information self-disclosure and non-official disclosure are intensified [7]. Based on different samples and studies methods, most of scholars at home and abroad disclose that minority shareholders have active governance roles [8-12]. Therefore, in order to improve the corporate governance, set up investors' confidence and stimulate the energy of capital market, studying governance behaviors of minority shareholders has an important practical significance.

\section{LITERATURES AND BACKGROUND}

Currently some scholars have adopted theory or case research method to discuss factors that influence the governance of minority shareholders behaviors. For example, $\mathrm{Xu}$ Xiangyi (2004) finds that except the judicial remedy system, shareholders' voting right (voting by hand at shareholders' meeting) and withdrawal right (voting with feet) are two methods for them to get benefits in corporate governance and control agents, and that the development of network technique will stir minority shareholders to participate in the corporate governance[13]. Based on theory model analysis, Zheng Xiutian (2015) finds that the behavior selection of minority shareholders are influenced by diverse factors by a listed company such as shareholding proportion, supervision cost, perfection probability of governance 
structure of listed company [10]. Based on case studies, Zhang Weiwei (2015) discloses that, in an Internet environment, the weakness position and high costs in supervision of minority shareholders are reduced, which raises their enthusiasm in the corporate governance[14]. Others have verified the factors that influence the governance of minority shareholders behaviors through empirical study method. Li Wenjing, Kong Dongmin et al (2012) discovered after studies that the participation degree through online voting by minority shareholders is higher [15] in companies where agencies of majority shareholders are serious and institutional investors holds higher share proportion. $\mathrm{Li}$ Wenjing, Kong Dongmin (2013) also discover that the worse the corporate information transparency is, the higher the enthusiasm of minority shareholders to vote; and ownership structure of a company will influence the participation degree of minority shareholders to vote, which is more obvious in companies whose information transparency is worse[16]. Kong Dingmin et al (2013) further discover that the corporate governance level is in a negative correlation with the participation degree through online voting by minority shareholders [11]. Ye Jianhong (2005), Wang Wei et al (2015) think that investors' attention can significantly low the abstentions of minority shareholders in voting[17].Yet Listokin (2010) thinks that even owning decision-making rights, minority shareholders cannot be guaranteed to actively carry out or efficiently execute the rights[18]. In a word, though the studies mentioned above play an indispensable role in disclosing the factors that influence the governance of shareholders behaviors, yet the sample range in most literatures got involved in full circulation and before the Internet is popularized, so the time validity of the research results are influenced. In addition, most literatures are focused on discussion through voting; having a perspective to integrate voting by hand and voting with feet to the same governance framework, and the discussion on relations between the two is also inadequate.

With the development of Internet and big data application, financial scholars at home and abroad start to research the influence of investors' attentions on stock prices or turnover. The literatures aim to clarify some abnormalities in capital markets, though it shows the roles of investors' attentions to voting with feet by minority shareholders to some degree, yet the corporate governance is not put into the scope that influence the decision-making of minority investors. Shen Yifeng, Yang Jing et al $(2013$; 2017) has discussed from online consensus though [23], yet it didn't get involved in the formal governance of minority shareholders behaviors.

In a word, promoted by the Internet environment in the country, corporate information has attracted eyeballs of investors, and the governance of shareholders is obvious gradually, which promotes domestic corporate governance urgently needs rights re-organization and mode innovation[24]. However, during the process, could minority shareholders still be indifferent as usual? In other words, does the governance get influenced obviously by the online attentions? Current research results have not given any ideal answer. Therefore, based on real background and existing literature, considering new trends of the Internet, this article will discuss the influences of investors' online attention on the two behaviors of minority shareholders to participate in the corporate governance which are integrated to the same governance framework. It will provide policy basis to securities authorities to further improve the voting or trading rules, doing good to provide theoretical supports to establish and perfect the voice and exit strategy of minority shareholders.

The marginal contribution of this article is mainly reflected in the following: First, in the Internet plus environment, based on the perspective of online attentions, it reveals the governance behaviors of minority shareholders, clarifying the relations between voting by hand and voting with feet in the same governance framework, enriching the corporate governance theoretical results.Second, it reveals the roles of investors' attentions from micro-level in baffling the corporate governance issues, expanding the research scope of investors' attentions into corporate finance.

This article has its structure arranged as follows: part II raises research hypothesis through theoretical analysis; part III states definition of variables used in this article and introduce proposed models; part IV provides empirical test aiming at main problems to be researched, and finally draws a conclusion and gives policy suggestion.

\section{THEORETICAL ANALYSIS AND RESEARCH HYPOTHESIS}

Xia Donglin (2000) thinks that the supervision of shareholders on operators (insiders) can be achieved through internal supervision as voting by hand and market supervision as voting with feet [25]. Therefore, this article will discuss the impact of online attentions of investors on governance behaviors of minority shareholders.

Online attentions may influence the governance of minority shareholders with voting by hand from many channels. First, seen from the corporate governance, the online attentions of minority shareholders may lead to supervision pressure over the company [26]. Supervised from the outside, the corporate internal governance mechanism will be further perfected, and minority shareholders will be more possible to declare themselves in the corporate decision making, which will for active and benignant circulation for governance. Second, seen from the motives of minority shareholders to participate in the governance, the higher attentions will reduce the information asymmetry of minority shareholders, make their behaviors more rational as well as give them stronger motivation to vote so as to make selfprotection. On the other hand, the gradual popularization of Internet and its terminals have greatly lowered the marginal costs of minority shareholders to vote online, reducing barriers causing their indifference, which will promote them to vote actively. Therefore, the higher the online attentions are, the more active the minority shareholders vote by hand so as to actively participate in the corporate governance. So this article raises the following hypothesis:

Hypothesis 1: In corporate governance, the online attention to the company will significantly increase the voting by hand behavior of minority shareholders. 
Zhang Jide (2014) thinks that the attentions of common investors will influence the stock market liquidity through attentions driving transactions and excessive trading. The former, based on psychology theory thought that the focuses of common investors on some stock will cause the stock to be sold and bought frequently in stock market. The latter, based on the behavioral finance theory, thought that Chinese common investors have over self confidence, instead the irrational response to information cause higher turnover [19]. Effected by the two mechanisms mentioned above, whether value investors ors or speculative traders ${ }^{\mathbb{1}}$, the online attentions of minority shareholders play positive roles in the influence of voting with feet. The higher the attentions of value investors to the company is, the more comprehensive and timely they get the corporate information. Once they know the corporate insiders may possibly have any motive or behavior to embezzle the benefits of minority shareholders, they will predict that the company is not worthy of being invested, which may cause their behaviors of voting with feet; speculative traders be focused on the company's short term stock price trend and trades of other investors. Promoted by the sheep flock effect, when the company's performances decline due to improper behaviors of some insiders, minority shareholders will make decisions to sell together with other investors as the stock price falls. So this article raises hypothesis as follows:

Hypothesis 2: In corporate governance, online attention to the company will significantly increase the voting with feet behavior of minority shareholders.

Weighed between benefits and costs, the company's online attentions may possibly change the indifference attitude of minority shareholders. Seen from costs, the gradual popularization of Internet and its terminals have greatly lowered the costs of minority shareholders to vote by hand. Seen from benefits, the voting by hand of minor shareholders will help prevent the approval of resolutions which will harm their benefits. The behaviors of voting by hand will recover more loss of minority shareholders and even gain benefits. Though the behavior of voting with feet needs lower direct costs, which may cause loss of benefits due to the participation in governance, there are some opportunity costs existing. So obviously, the higher the online attentions are, the higher the insiders of the company will be supervised, and compared to voting with feet, the voting by hand of minority shareholders can greatly reduce the loss and even increase benefits, so the governance effect is better, which will promote minority shareholders to have preference to voting by hand, lowering the indifferences. On the contrary, when the online attentions of the company decline, the external supervision on the company formed by them will be weakened as well, and minority shareholders are unable to contend with the company's insiders, and it will be more difficult to vote by hand to recover the loss, causing more indifference, further the embezzlement of benefits even cause to less performances of the company, and minority

${ }^{(1)}$ According to Xie Shifei (2015), value investors mainly refer to those who take the value of stock as basis for decision making. Speculators mainly take short term stock price tendency, market popularity, psychologies of other investors as basis for decision making, full of motives of speculation ${ }^{[3]}$. shareholders have to pay for the stock price fall, at that moment, they are much more tending to leave (vote with feet). So we raise the following research hypothesis:

Hypothesis 3: The higher the company's online attentions are, the stronger the preference of minority shareholders to vote by hand is; otherwise, the stronger the preference of minority shareholders to vote with feet.

\section{RESEARCH DESIGN}

\section{A. Sampling and Data Source}

Since this article mainly investigates the influence of online attentions on minority shareholders behaviors in the Internet environment after full circulation, so the sampling scope was from 2009 to 2015. During the period, domestic listed companies had completed Full Circulation Reform, internet had made a great development and became an indispensable medium to access to information of companies, so it can provide ideal samples meeting this research. This article takes 1591 listed companies in Shanghai and Shenzhen before 2009. After ST listed companies and some missing samples removed, there are 9731 samples left. The online attentions data are taken from the data channel of Hexun.com ${ }^{2}$, while other data are from GTA database.

\section{B. Definition of Variables}

The dependent variables that the article inspects is minority shareholders behaviors, namely vote by hand and vote with feet and behavior preference, while the independent variable is investors' online attentions. Based on relevant literatures, this article adds other control variables; details of main variables are given as follows:

1) Vote by hand: considering costs for voting, most of minority shareholders are unwilling to vote in situ or authorize board of director to do it, instead, most of minority shareholders are unwilling to vote in situ or authorize board of director to do it, instead, they tend to participate in the corporate governance via online voting. The direct datas of online voting by minority shareholders after 2009 are unavailable, so according to the studies on shareholders presence for voting by Xin Tiancai and Zong Jichuan (2009), this article takes the relative proportion of number of shareholders attending the shareholders meeting as proxy variable $^{3}$ to weigh the participation of minority shareholders to vote by hand:

$$
\text { Vote }_{\mathrm{i}, \mathrm{t}}=\frac{\text { Vote }_{\mathrm{i}, \mathrm{t}}-\text { Votex }_{\mathrm{i}, \mathrm{t}}}{1+\operatorname{Votex}_{\mathrm{i}, \mathrm{t}}}
$$

Where, Votew $_{i, t}$ is average number of shareholders attending the shareholders meeting online (including majority

\footnotetext{
${ }^{(2)}$ Hexun.com (http://www.hexun.com) is a professional financial website with higher influence at home, and its data channel is also the largest, authoritative, professional and mostly beloved, so it has high authority and authenticity.

${ }^{3}$ Considering that minority shareholders have a low proportion of individual shares but occupy a large number of shareholders, we can ignore the difference in shareholding between individuals to some degree.
} 
and minority shareholders), Votex $x_{i, t}$ is average number of shareholders attending the shareholders meeting offline (mainly majority shareholders) ${ }^{4}$.

2) Vote with feet: most of scholars think that the selling of minority shareholders may cause stock price fall, which will pressure companies, showing its governance effect. Therefore, for the governance behaviors of minority shareholders, this article weighs it through selling proportion of minority shareholders, namely:

$$
\text { Sell }_{\mathrm{i}, \mathrm{t}}=1-\text { Ltonva }_{\mathrm{i}, \mathrm{t}}
$$

Where, Ltonva $_{\mathrm{i}, \mathrm{t}}$ is a proportion of big deal selling accumulated trade volume in the total selling volume in a market day, which generally represents the proportion of average selling volume of institutional investors or those holding higher share proportions, so Sell $_{i, t}$ represents the proportion of average selling business volume by minority shareholders of that year.

3) Preference of governance behaviors: this article adopts the relative ratio between above mentioned participation through voting by hand and voting with feet to weigh, namely:

$$
\operatorname{Vts}_{\mathrm{i}, \mathrm{t}}=\frac{\text { Vote }_{\mathrm{i}, \mathrm{t}}}{\text { Sell }_{\mathrm{i}, \mathrm{t}}}
$$

4) Investor online attention: Initially scholars just weigh investors' attentions through indirect proxy variable, for example, Barber and Odean (2008) adopted excess earning, turnover or new headline and so on. However, the variables contain potentially a non-objective key hypothesis, namely if a stock is reported by media, investors will pay attention to it. Actually it is not always true. With the Internet mature increasingly, in recent years, some scholars start to weigh investors attentions through Google or Baidu search index[28][29], yet it cannot exclude those users of comprehensive websites with search purposes except investment, so there is plenty of noise from non-investors' information search which may bring high disturbance to weigh the attentions of real investors. Therefore, based on the mentioned thoughts above, this article references the data of Wang Yong, Yang Qingyun (2014) and Wu Dejun[30,31], gets attention data of stocks at the data channel of Hexun.com through Python technique ${ }^{5}$ to weigh the online attention to listed companies, which can be more efficient and prudent, namely:

$$
A t t_{\mathrm{it}}=\operatorname{Ln}\left(\operatorname{Index}_{\mathrm{it}}\right)
$$

\footnotetext{
${ }^{4}$ GTA database divides the shareholders meeting into voting in situ, voting online, authorizing board of director to vote or combination of any of the above. In order to make it easy to express, this article calls the shareholders meetings held via voting online as the online voting shareholders meeting, and those not held via voting online as the non-online voting shareholders meeting.

(5) The index originates from the big data that are generated at website background by users' searches or browsing of company news online, which can directly reflect investors' attentions to information of listed companies and its changes.
}

Where, Index $x_{i t}$ is stock attention indices of Hexun.com data channel.

Besides, investors' attentions to corporate information are dynamic, so referencing thoughts of DA, ZHI et al (2011), Liu Feng et al(2015), Fan, Xiaoqian, et al (2017), this article uses abnormal attention indice which is the change rate of current attention relative to previous attention, so as to show robust results, namely:

$$
A b a t t_{\text {it }}=A t t_{\text {it }}-A t t_{\text {it }-1}
$$

\begin{tabular}{|c|c|c|}
\hline Symbol & Name of variables & Definition of variables \\
\hline Vote & $\begin{array}{l}\text { Participation of voting } \\
\text { by hand }\end{array}$ & $\begin{array}{l}\text { Proportion between numbers of } \\
\text { minority shareholders and majority } \\
\text { shareholders attending the } \\
\text { shareholders meeting }\end{array}$ \\
\hline Sell & $\begin{array}{l}\text { Proportion of voting } \\
\text { with feet }\end{array}$ & $\begin{array}{l}\text { Percentage of selling volumes by } \\
\text { minority shareholders in total selling } \\
\text { volumes }\end{array}$ \\
\hline Vts & $\begin{array}{l}\text { Governance behavior } \\
\text { preference }\end{array}$ & $\begin{array}{l}\text { Preference to voting by hand } \\
\text { compared to voting with feet }\end{array}$ \\
\hline Att & General attention & $\begin{array}{l}\text { Natural logarithm of stock attentions } \\
\text { by investors }\end{array}$ \\
\hline Abatt & Abnormal attention & $\begin{array}{l}\text { Change of current attention compared } \\
\text { to that in previous year }\end{array}$ \\
\hline Dual & $\begin{array}{l}\text { The duality of the } \\
\text { Director Chairman } \\
\text { and CEO }\end{array}$ & $\begin{array}{l}\text { Take } 1 \text { if Director Chairman is CEO, } \\
\text { otherwise } 0 \text { if not. }\end{array}$ \\
\hline Outd & $\begin{array}{l}\text { Number of } \\
\text { independent director }\end{array}$ & $\begin{array}{l}\text { Weigh the corporate internal } \\
\text { supervision level }\end{array}$ \\
\hline Herf & $\begin{array}{l}\text { Share holding index } \\
\text { of top ten } \\
\text { shareholders }\end{array}$ & $\begin{array}{l}\text { quadratic sum of shareholding } \\
\text { proportion to top ten shareholders, } \\
\text { weigh the corporate ownership } \\
\text { concentration }\end{array}$ \\
\hline Inst & $\begin{array}{l}\text { Shareholding } \\
\text { proportion of } \\
\text { institutional investors }\end{array}$ & $\begin{array}{l}\text { Total shareholding proportion of } \\
\text { institutional investors }\end{array}$ \\
\hline $\begin{array}{c}\text { Separatio } \\
n\end{array}$ & $\begin{array}{l}\text { Separation of control } \\
\text { and ownership }\end{array}$ & $\begin{array}{l}\text { Balance between control right and } \\
\text { ownership of actual controller in a } \\
\text { listed company }\end{array}$ \\
\hline ROE & Return on Equity & $\begin{array}{l}\mathrm{ROE}=\text { net profits/equality, reflecting } \\
\text { the shareholder's profitability }\end{array}$ \\
\hline Tie & Interest coverage ratio & $\begin{array}{l}\text { TIE = Earnings Before Interest and } \\
\text { Tax/interest, reflecting the } \\
\text { company's debt paying ability }\end{array}$ \\
\hline Soe & $\begin{array}{l}\text { State-owned } \\
\text { enterprise }\end{array}$ & $\begin{array}{l}1=\text { state-owned enterprise; } 0=\text { non- } \\
\text { state enterprise }\end{array}$ \\
\hline Growth & Growth rate of sales & Weigh the corporate growth \\
\hline Asset & Assets size & $\begin{array}{l}\text { Natural logarithm of corporate total } \\
\text { assets book value }\end{array}$ \\
\hline Sn & Shareholder number & $\begin{array}{l}\text { Natural logarithm of number of } \\
\text { shareholders }\end{array}$ \\
\hline Outshares & $\begin{array}{l}\text { Proportion of } \\
\text { outstanding shares }\end{array}$ & $\begin{array}{l}\text { Proportion of outstanding shares in } \\
\text { total shares }\end{array}$ \\
\hline Industry & Industry variable & 12 industry dummy variables ${ }^{(6)}$ \\
\hline Year & Year variable & $6 \quad$ Year variables \\
\hline
\end{tabular}

5) Control variables: Description of control variables is given as "Table I".

TABLE I. DEFINITION AND DESCRIPTION OF MAIN VARIABLES

Referring to given literatures [16], in addition, this article adds some corporate governance variables, where, internal

${ }^{(6)}$ This article classifies the sampled companies as per Industry Classification Guide for Listed Companies by China Securities Regulatory Commission (2012), and some industries with few samples are integrated to other industries, getting 12 industry dummy variables. 
governance variables mainly include: The duality of the Director Chairman and CEO, ownership concentration, separation of control and ownership, number of independent director, duality of Board Chairman and CEO; external governance variable is mainly shareholding proportion of institutional investors. In addition, this article follows habits of corporate governance studies, adding corporate characteristic variables such as return on equity, interest coverage ratio, sales growth rate, assets size, shareholders numbers, proportion of tradable shares, state-owned enterprise or not, year dummy variables and industry dummy variables.

\section{Model Setting}

In order to analyze the influence of online attentions on the governance behaviors of minority shareholders, this article builds a model as follows (6), and adopts fixed effect according to Hausman's test results.

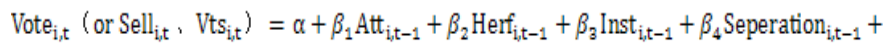
$\beta_{5}$ Outd $_{\mathrm{i}, \mathrm{t}-1}+\beta_{6}$ Dual $_{\mathrm{i}, \mathrm{t}-1}+\beta_{7} \mathrm{Tie}_{\mathrm{i}, \mathrm{t}-1}+\beta_{8} \mathrm{ROE}_{\mathrm{i}, \mathrm{t}-1}+\beta_{9}$ Growth $_{\mathrm{i}, \mathrm{t}-1}+\beta_{10}$ Asset $_{\mathrm{i}, \mathrm{t}-1}+$ $\beta_{11}$ Sn $_{i, t-1}+\beta_{12}$ Outshares $_{\mathrm{i}, t-1}+\beta_{13}$ Soe $_{\mathrm{i}, \mathrm{t}}+$ EIndustry $+\sum$ Year $+\varepsilon_{\mathrm{i}, \mathrm{t}}$ (6)

Where, dependent variable Vote $_{i, t}$. Sell $\mathrm{i}_{\mathrm{i}, \mathrm{t}}$ or $^{\mathrm{Vts} \mathrm{i}, \mathrm{t}}$, respectively stand for governance behavior of voting by hand, governance behavior of voting with feet and preference of governance behavior. In order to guarantee a robust result, this article replaces ${ }^{A t t_{i, t}}$ with ${ }^{A b a t t}{ }_{i, t}$ in the mode for testing. All the other independent variables are controlled with one-step lag except Soe, Industry and Year.

\section{EMPIRICAL TEST AND ANALYSIS}

\section{A. Descriptive Statistics} II".

Descriptive statistics of all variables are given in "Table

TABLE II. DESCRIPTIVE STATISTICS OF VARIABLES

\begin{tabular}{|c|c|c|c|c|c|}
\hline Variables & $\begin{array}{c}\text { Observed } \\
\text { Value }\end{array}$ & $\begin{array}{c}\text { Average } \\
\text { Value }\end{array}$ & $\begin{array}{l}\text { Standard } \\
\text { Deviation }\end{array}$ & $\begin{array}{c}\text { Min } \\
\text { Value }\end{array}$ & $\begin{array}{c}\text { Max } \\
\text { Value }\end{array}$ \\
\hline Vote & 9731 & 21.99 & 111.8 & -0.999 & 6065 \\
\hline Sell & 9714 & 0.893 & 0.0507 & 0.238 & 0.982 \\
\hline Att & 9731 & 7.629 & 0.806 & 4.844 & 10.62 \\
\hline Abatt & 7644 & -0.00961 & 0.0717 & -0.263 & 0.347 \\
\hline Herf & 9731 & 0.165 & 0.127 & $\begin{array}{l}2.00 \mathrm{e}- \\
05\end{array}$ & 0.810 \\
\hline Inst & 9731 & 7.151 & 10.43 & 0.0400 & 86.31 \\
\hline Seperation & 9151 & 5.986 & 8.266 & 0 & 45.49 \\
\hline Outd & 9702 & 3.334 & 0.750 & 0 & 8 \\
\hline Dual & 9575 & 0.165 & 0.371 & 0 & 1 \\
\hline Tie & 9544 & 4.599 & 770.7 & -45243 & 42909 \\
\hline ROE & 9730 & 0.102 & 8.051 & -167.1 & 713.2 \\
\hline Growth & 9718 & 16.17 & 1374 & -1 & 134607 \\
\hline Asset & 9730 & 22.28 & 1.565 & 11.35 & 30.73 \\
\hline Sn & 9223 & 10.68 & 0.874 & 8.236 & 14.18 \\
\hline Outshares & 9731 & 0.844 & 0.224 & 0.0247 & 1 \\
\hline Soe & 9731 & 0.588 & 0.492 & 0 & 1 \\
\hline
\end{tabular}

In "Table II", the average value of voting by hand is 21.99 , which reflects that minority shareholders have some degree of participation at shareholders meeting through online voting, meanwhile, according to the standard deviation, the relative participation in shareholders meeting by minority shareholders is highly fluctuant ${ }^{(7}$, the max value reaches 6065 , which is far more than the number of majority shareholders attending the shareholders meeting. Yet the participation of minority shareholders voting with feet is higher, whose average value reaches 0.893 in a low fluctuation, which is kept at the level. In addition, the minimum online attention reaches 4.844 , which means that corporate online information that attract attentions of social shareholders has been popular.

\section{B. Regression Analysis}

1) Analyzing the influence of online attentions on voting by hand of minority shareholders

TABLE III. REGRESSION RESULT OF ONLINE ATTENTION AND VOTING BY HAND

\begin{tabular}{|c|c|c|c|c|}
\hline & \multicolumn{4}{|c|}{ Dependent Variable: Vote } \\
\hline Variables & (1) & (2) & (3) & (4) \\
\hline \multirow[t]{2}{*}{ Att } & $16.50 * * *$ & $15.47 * * *$ & & \\
\hline & $(3.459)$ & $(3.622)$ & & \\
\hline \multirow[t]{2}{*}{ Abatt } & & & $56.89 * * *$ & $64.82 * * *$ \\
\hline & & & $(19.72)$ & $(20.56)$ \\
\hline \multirow[t]{2}{*}{ Herf } & & $-68.72 *$ & & $-68.84 *$ \\
\hline & & $(37.22)$ & & $(37.25)$ \\
\hline \multirow[t]{2}{*}{ Inst } & & 0.433 & & 0.515 \\
\hline & & $(0.366)$ & & $(0.365)$ \\
\hline \multirow[t]{2}{*}{ Seperation } & & -0.378 & & -0.401 \\
\hline & & $(0.453)$ & & $(0.453)$ \\
\hline \multirow[t]{2}{*}{ Outd } & & -0.417 & & -0.433 \\
\hline & & $(4.513)$ & & $(4.517)$ \\
\hline \multirow[t]{2}{*}{ Dual } & & -0.808 & & -0.504 \\
\hline & & $(6.336)$ & & $(6.340)$ \\
\hline \multirow[t]{2}{*}{ Tie } & $0.002 *$ & $0.002 * *$ & $0.002 *$ & $0.002 *$ \\
\hline & $(0.00241)$ & $(0.00244)$ & $(0.00241)$ & $(0.00245)$ \\
\hline \multirow[t]{2}{*}{$R O E$} & -0.222 & -0.244 & -0.172 & -0.0975 \\
\hline & $(0.523)$ & $(0.927)$ & $(0.523)$ & $(0.927)$ \\
\hline \multirow[t]{2}{*}{ Growth } & -0.000109 & $-7.29 \mathrm{e}-05$ & -0.000132 & -0.000103 \\
\hline & $(0.000847)$ & $(0.000846)$ & $(0.000848)$ & $(0.000847)$ \\
\hline \multirow[t]{2}{*}{ Asset } & $-8.840 * *$ & -6.187 & $-6.919 *$ & -4.551 \\
\hline & $(4.091)$ & $(4.476)$ & $(4.080)$ & $(4.467)$ \\
\hline \multirow[t]{2}{*}{$S n$} & -3.141 & -5.925 & 2.178 & -1.101 \\
\hline & $(4.575)$ & $(4.838)$ & $(4.398)$ & $(4.644)$ \\
\hline \multirow[t]{2}{*}{ Outshares } & -10.42 & -11.31 & -9.568 & -10.69 \\
\hline & $(9.669)$ & $(10.23)$ & $(9.686)$ & $(10.24)$ \\
\hline \multirow[t]{2}{*}{ Soe } & -1.340 & -2.565 & -1.085 & -2.064 \\
\hline & $(12.10)$ & $(13.33)$ & $(12.12)$ & (13.34) \\
\hline \multirow[t]{2}{*}{ Constant } & 162.9 & 136.1 & $176.0 *$ & 153.4 \\
\hline & $(103.3)$ & $(117.0)$ & $(103.5)$ & $(117.1)$ \\
\hline Industry & Yes & Yes & Yes & Yes \\
\hline Year & Yes & Yes & Yes & Yes \\
\hline Observations & 7,063 & 6,540 & 7,063 & 6,540 \\
\hline$R$-squared & 0.030 & 0.029 & 0.028 & 0.028 \\
\hline Number of code & 1,467 & 1,437 & 1,467 & 1,437 \\
\hline
\end{tabular}

a. Note: Standard deviation, $* * *, * *$ and $*$ in brackets here means that estimation coefficient is significant at the significance levels of $1 \%, 5 \%$ and $10 \%$. Where model (1)-(2) is to test the influence of general attention on the voting by hand of minority shareholders; model (3)-(4) is to test the influence of abnormal attention on the voting by hand of minority shareholders.

In order to test the hypothesis 1 of this article, we use model (6) with general attention (Att) and abnormal attention (Abatt) respectively, and the result is given as "Table III":

${ }^{(7)}$ In fact, judged from data, the participation of minority shareholders voting by hand is increasing year by year. Due to limited space here, no details are given. 
The regression results of 4 models in Table 3 show that with any control variables added, the online attention keeps positive correlation with voting by hand, which is significant at the level $1 \%$, which proves the hypothesis 1 given by this article.

2) Analyzing the influence of online attention on voting with feet of minority shareholders

TABLE IV. REGRESSION RESULTS OF ONLINE ATTENTION AND VOTING WITH FEET

\begin{tabular}{|c|c|c|c|c|}
\hline & \multicolumn{4}{|c|}{ Dependent Variable: Sell } \\
\hline Variables & (1) & (2) & (3) & (4) \\
\hline \multirow[t]{2}{*}{ Att } & $0.0109^{* * *}$ & $0.0105 * * *$ & & \\
\hline & $(0.0013)$ & $(0.00131)$ & & \\
\hline \multirow[t]{2}{*}{ Abatt } & & & $0.0240 * * *$ & $0.0240 * * *$ \\
\hline & & & $(0.0078)$ & $(0.0081)$ \\
\hline \multirow[t]{2}{*}{ Inst } & & 0.000152 & & $0.0002 *$ \\
\hline & & $(0.0001)$ & & $(0.0001)$ \\
\hline \multirow[t]{2}{*}{ Herf } & & $0.0458 * * *$ & & $0.0443 * * *$ \\
\hline & & $(0.0147)$ & & $(0.0147)$ \\
\hline \multirow{2}{*}{ Seperation } & & 0.0002 & & 0.0002 \\
\hline & & $(0.0002)$ & & $(0.0002)$ \\
\hline \multirow[t]{2}{*}{ Outd } & & 0.0015 & & 0.0014 \\
\hline & & $(0.0017)$ & & $(0.0017)$ \\
\hline \multirow[t]{2}{*}{ Dual } & & $0.0050 * *$ & & $0.0053 * *$ \\
\hline & & $(0.0024)$ & & $(0.0024)$ \\
\hline \multirow[t]{2}{*}{ Tie } & $6.22 \mathrm{e}-07$ & $4.20 \mathrm{e}-07$ & $4.66 \mathrm{e}-07$ & $2.56 \mathrm{e}-07$ \\
\hline & $(9.06 \mathrm{e}-07)$ & $(9.14 \mathrm{e}-07)$ & $(9.11 \mathrm{e}-07)$ & $(9.19 \mathrm{e}-07)$ \\
\hline \multirow[t]{2}{*}{$R O E$} & $0.0005 * *$ & 0.0003 & $0.0005^{* * * *}$ & 0.0004 \\
\hline & $(0.0002)$ & $(0.0004)$ & $(0.0002)$ & $(0.0004)$ \\
\hline \multirow[t]{2}{*}{ Growth } & $8.95 \mathrm{e}-07 * * *$ & $8.81 \mathrm{e}-07 * * *$ & $8.88 \mathrm{e}-07 * * *$ & $8.77 \mathrm{e}-7$ *** \\
\hline & $(3.23 \mathrm{e}-07)$ & $(3.21 \mathrm{e}-07)$ & $(3.25 \mathrm{e}-07)$ & $(3.23 \mathrm{e}-07)$ \\
\hline \multirow[t]{2}{*}{ Asset } & $0.0060^{* * * *}$ & $0.0062 * * *$ & $0.0078^{* * * *}$ & $0.0078 * * *$ \\
\hline & $(0.0015)$ & $(0.0016)$ & $(0.0015)$ & $(0.0016)$ \\
\hline \multirow[t]{2}{*}{$S n$} & $0.0070 * * *$ & $0.0083^{* * * *}$ & $0.00770 * * *$ & $0.0093 * * *$ \\
\hline & $(0.0018)$ & $(0.0020)$ & $(0.0019)$ & $(0.0020)$ \\
\hline \multirow[t]{2}{*}{ Outshares } & -0.0043 & -0.0017 & -0.0041 & -0.0016 \\
\hline & $(0.0034)$ & $(0.0037)$ & $(0.0034)$ & $(0.0037)$ \\
\hline \multirow[t]{2}{*}{ Soe } & -0.0012 & -0.0005 & -0.000749 & $3.10 \mathrm{e}-05$ \\
\hline & $(0.0046)$ & $(0.0051)$ & $(0.0047)$ & $(0.0051)$ \\
\hline \multirow[t]{2}{*}{ Constant } & $0.621 * * *$ & $0.594 * * *$ & $0.648 * * *$ & $0.619 * * *$ \\
\hline & $(0.0407)$ & $(0.0455)$ & \begin{tabular}{|l}
$(0.0409)$ \\
\end{tabular} & $(0.0457)$ \\
\hline Industry & Yes & Yes & Yes & Yes \\
\hline Year & Yes & Yes & Yes & Yes \\
\hline Observations & 7,092 & 6,566 & 7,092 & 6,566 \\
\hline$R$-squared & 0.086 & 0.089 & 0.075 & 0.079 \\
\hline Number of code & 1,474 & 1,441 & 1,474 & 1,441 \\
\hline
\end{tabular}

b. Note: Standard deviation, $* * * * *$ and $*$ in brackets here means that estimation coefficient is significant at the significance levels of $1 \%, 5 \%$ and $10 \%$. Where model (1)-(2) is to test the influence of general attention on the voting by hand of minority shareholders; model (3)-(4) is to test the influence of abnormal attention on the voting by hand of minority shareholders.

Next, we will prove the hypothesis 2 , that is the influence of online attention on the voting with feet, and then conduct analysis of regression with the above mentioned models, all regression results are given in "Table IV".

According to the regression results of "Table IV", not only general attention but also abnormal attention has positive influence on the voting with feet by minority shareholders at significant level of $1 \%$. Therefore, the hypothesis 2 is proved, that is, the online attention of investors can promote the voting with feet of minority shareholders.

3) The influence of online attention on two governance behaviors of minority shareholders: This article further test the influence of online attention on the preference of governance behaviors of minority shareholders. Regression is conducted with model (6), and the results are given in "Table V":

TABLE V. INFLUENCE OF ONLINE ATTENTION ON PREFERENCE OF GOVERNANCE BEHAVIORS OF MINORITY SHAREHOLDERS

\begin{tabular}{|c|c|c|c|c|}
\hline & \multicolumn{4}{|c|}{ Dependent Variable: Vts } \\
\hline Variables & (1) & (2) & (3) & (4) \\
\hline \multirow{2}{*}{$A t t$} & $18.22 * * *$ & $15.53 * * *$ & & \\
\hline & $(3.215)$ & $(3.884)$ & & \\
\hline \multirow[t]{2}{*}{ Abatt } & & & $75.85 * * *$ & $73.59 * * *$ \\
\hline & & & $(24.17)$ & $(23.79)$ \\
\hline \multirow[t]{2}{*}{ Inst } & & 0.435 & & 0.599 \\
\hline & & $(0.425)$ & & $(0.425)$ \\
\hline \multirow[t]{2}{*}{ Herf } & & $-76.97 *$ & & $-78.06^{*}$ \\
\hline & & $(43.43)$ & & $(43.46)$ \\
\hline \multirow[t]{2}{*}{ Seperation } & & -0.362 & & -0.402 \\
\hline & & $(0.509)$ & & $(0.509)$ \\
\hline \multirow[t]{2}{*}{ Outd } & & -2.169 & & -2.125 \\
\hline & & $(5.073)$ & & $(5.077)$ \\
\hline \multirow[t]{2}{*}{ Dual } & & -1.191 & & -0.771 \\
\hline & & $(7.102)$ & & $(7.105)$ \\
\hline \multirow[t]{2}{*}{ Tie } & & 0.00231 & & 0.00213 \\
\hline & & $(0.00270)$ & & $(0.00271)$ \\
\hline \multirow[t]{2}{*}{$R O E$} & & -0.469 & & -0.315 \\
\hline & & $(1.042)$ & & $(1.042)$ \\
\hline \multirow[t]{2}{*}{ Growth } & & -0.000115 & & -0.000147 \\
\hline & & $(0.000951)$ & & $(0.000952)$ \\
\hline \multirow[t]{2}{*}{ Asset } & & -7.714 & & -5.572 \\
\hline & & $(4.791)$ & & $(4.750)$ \\
\hline \multirow[t]{2}{*}{ Sn } & & -1.716 & & 2.299 \\
\hline & & $(5.776)$ & & $(5.973)$ \\
\hline \multirow[t]{2}{*}{ Outshares } & & -4.936 & & -4.670 \\
\hline & & $(10.96)$ & & $(10.97)$ \\
\hline \multirow[t]{2}{*}{ Soe } & & 6.590 & & 7.182 \\
\hline & & $(14.97)$ & & $(14.98)$ \\
\hline \multirow[t]{2}{*}{ Constant } & $-123.9 * * *$ & 120.8 & 0.435 & 136.4 \\
\hline & $(42.40)$ & $(134.8)$ & $(46.40)$ & $(134.8)$ \\
\hline Industry & Yes & Yes & Yes & Yes \\
\hline Year & Yes & Yes & Yes & Yes \\
\hline Observations & 7629 & 6,564 & 7,629 & 6,564 \\
\hline R-squared & 0.028 & 0.029 & 0.028 & 0.028 \\
\hline Number of code & 1,572 & 1,441 & 1,552 & 1,441 \\
\hline
\end{tabular}

c. Note: Standard deviation, $* * *, * *$ and $*$ in brackets here means that estimation coefficient is significan at the significance levels of $1 \%, 5 \%$ and $10 \%$. Where model (1)-(2), (3)-(4) are the influences of general attention and abnormal attention on the preference of governance behaviors.

According to the regression results of "Table V", not only general attention but also abnormal attention, whether control variables are added or not, all have positive correlation with the preference of governance behavior and are significant at the level of $1 \%$. It means that when the online attention increases, minority shareholders have preferences to voting by hand with the indifference lowered; otherwise, they have preferences to voting with feet with the indifference raised, so the hypothesis 3 in this article is proved.

\section{Robustness Test}

In order to keep the conclusion robust, this article conducts robust tests on the above mentioned test results:

1) Rebuilding the relative participation index: This article adopts log-taking method, rebuilding the relative participation index of voting by hand of minority shareholders, namely:

$$
\text { Vote } 2_{i, t}=\ln \left(1+\text { Votew }_{i, t}\right)-\ln \left(1+\text { Votex }_{i, t}\right)
$$


Where, Votew $w_{i, t}$ is average of number of attendees at online voting shareholders meeting, Votex $_{i, t}$ is average of number of attendees at non-online voting shareholders meeting.

In addition, this article adopts the proportion of selling volume except big deals to weigh the participation of voting with feet of minority shareholders:

$$
\text { Sell }_{\mathrm{i}, \mathrm{t}}=1-\text { Ltonum }_{\mathrm{i}, \mathrm{t}}
$$

Where, Ltonum $_{\mathrm{i}, \mathrm{t}}$ is the proportion of accumulated selling volume of big deals in total selling volume on the market day.

Replacing Vote $_{\mathrm{i}, \mathrm{t}}$ and Sell $\mathrm{i}_{\mathrm{i}, \mathrm{t}}$ with $\operatorname{Vote}_{\mathrm{i}, \mathrm{t}}$ and $\operatorname{Sell}_{\mathrm{i}, \mathrm{t}}$ respectively, conducting regression with model (6), the results are given in "Table VI".

TABLE VI. INFLUENCE OF ONLINE ATTENTION ON GOVERNANCE BEHAVIORS OF MiNORITY SHAREHOLDERS

\begin{tabular}{|c|c|c|c|c|c|c|}
\hline \multirow[b]{2}{*}{ Variables } & \multicolumn{2}{|c|}{ Vote2 } & \multicolumn{2}{|c|}{ Sell2 } & \multicolumn{2}{|c|}{ Vts2 } \\
\hline & (1) & (2) & (3) & (4) & (5) & $(6)$ \\
\hline \multirow[t]{2}{*}{ Att } & $0.441 * * *$ & & $0.0105 * * *$ & & $0.367 * * *$ & \\
\hline & $(0.0677)$ & & $(0.00131)$ & & $(0.0732)$ & \\
\hline \multirow[t]{2}{*}{ Abatt } & & $1.466^{* * *}$ & & $0.0235 * * *$ & & $1.368 * * *$ \\
\hline & & $(0.385)$ & & $(0.00806)$ & & $(0.449)$ \\
\hline Control variable & Yes & Yes & Yes & Yes & Yes & Yes \\
\hline \multirow[t]{2}{*}{ Constant } & $12.61 * * *$ & $13.04 * * *$ & $0.600 * * *$ & $0.625 * * *$ & $12.62 * * *$ & $13.18 * * *$ \\
\hline & $(2.187)$ & $(2.193)$ & $(0.0455)$ & $(0.0457)$ & $(2.540)$ & $(2.542)$ \\
\hline Observations & 6,540 & 6,540 & 6,564 & 6,564 & 6,564 & 6,564 \\
\hline R-squared & 0.345 & 0.341 & 0.087 & 0.077 & 0.338 & 0.336 \\
\hline Number of code & 1,437 & 1,437 & 1,441 & 1,441 & 1,441 & 1,441 \\
\hline
\end{tabular}

d. Note: Standard deviation, $* * *, * *$ and $*$ in brackets here means that estimation coefficient is significant at the significance levels of $1 \%, 5 \%$ and $10 \%$.

The results in "Table VI" prove that the influence of online attention on governance behaviors of minority shareholders is positively significant at the level of $1 \%$, the hypothesis 1 to 3 are proved once again, which provide the robustness of the conclusion in this article.
2) Building a dynamic panel regression model: Some economic theories think that current behaviors of individuals may depend on the past ones, so this article further builds a dynamic panel regression model, and adopts system GMM to test the above mentioned hypothesis 1-3.

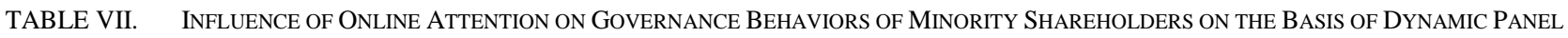

\begin{tabular}{|c|c|c|c|c|c|c|}
\hline \multirow[b]{2}{*}{ Variables } & \multicolumn{2}{|c|}{ Vote } & \multicolumn{2}{|c|}{ Sell } & \multicolumn{2}{|r|}{ Vts } \\
\hline & (1) & (2) & (3) & (4) & (5) & (6) \\
\hline \multirow[t]{2}{*}{ L.Vote } & 0.0631 & 0.0647 & & & & \\
\hline & $(0.0507)$ & $(0.0519)$ & & & & \\
\hline \multirow[t]{2}{*}{ Att } & $12.94 * * *$ & & $0.0106^{* * * *}$ & & $12.21 * * *$ & \\
\hline & $(3.175)$ & & $(0.00187)$ & & $(3.207)$ & \\
\hline \multirow[t]{2}{*}{ L.Sell } & & & $0.115^{* * * *}$ & $0.125 * * *$ & & \\
\hline & & & $(0.0293)$ & $(0.0299)$ & & \\
\hline \multirow[t]{2}{*}{ Abatt } & & $39.10 * *$ & & $0.0267 * * *$ & & $44.17 * * *$ \\
\hline & & $(15.27)$ & & $(0.01000)$ & & $(16.95)$ \\
\hline \multirow[t]{2}{*}{ L.Vts } & & & & & 0.0697 & 0.0706 \\
\hline & & & & & $(0.0523)$ & $(0.0530)$ \\
\hline Control variable & Yes & Yes & Yes & Yes & Yes & Yes \\
\hline \multirow[t]{2}{*}{ Constant } & 57.45 & 82.05 & $0.634 * * *$ & $0.675 * * *$ & -56.30 & -28.19 \\
\hline & $(142.5)$ & $(155.3)$ & $(0.0727)$ & $(0.0715)$ & $(137.6)$ & $(142.5)$ \\
\hline Observations & 6,540 & 6,540 & 6,558 & 6,558 & 6,558 & 6,558 \\
\hline Number of code & 1,437 & 1,437 & 1,441 & 1,441 & 1441 & 1441 \\
\hline
\end{tabular}

e. Note: Standard deviation, $* * *, * *$ and $*$ in brackets here means that estimation coefficient is significant at the significance levels of $1 \%, 5 \%$ and $10 \%$.

Results in "Table VII" show, online attention and voting by hand and voting with feet by minority shareholders are in positive correlation significantly.

This article further conducts autocorrelation test on disturbance items of the above mentioned system GMM. The results show: when the regression is done by Att or Abatt to Vote, the disturbance differences all have no first order autocorrelation and second order autocorrelation, Value $\mathrm{P}$ is equal to $0.2113,0.1144,0.2108$ and 0.1095 respectively so the GMM estimation is feasible. When a regression is conducted by Att or Abtt to Sell, the disturbance differences all have first order autocorrelation but without second order autocorrelation, and the value $\mathrm{P}$ is equal to 0.1721 and 0.1249 respectively, meeting the null hypothesis, and the GMM is feasible. When a regression is conducted by Att or Abtt to Vts, the value $\mathrm{P}$ for autocorrelation test is equal to $0.1756,0.1176$, 0.1752 and 0.1174 respectively, that is, none of the disturbance differences have first order or second order autocorrelation, and the GMM is feasible for estimation. Finally the above mentioned system GMM adopt 50 instrumental variables, so this article continues to conduct the over identifying test. The value $\mathrm{P}$ is equal to $0.5968,0.5979$, $0.2198,0.2747,0.5574$ and 0.1174 respectively, so six regression results show the null hypothesis of "all instrumental variables are valid" are acceptable. Therefore, hypothesis 1-3 are proved once again, which means the results are robust. 
In conclusion, whether main variable are replaced or research methods are changed, all hypothese in this article have been verified and the test results are highly robust.

\section{CONCLUSION AND SUGGESTION}

The gradual popularity of Internet has enhanced the corporate information disclosure and the supervision of the outside stockholders, which reducing the costs of minority shareholders access to information and the corporate governance. Facing such a situation, this article uses the stock attention data of Hexun financial data channel to research and finds that online attentions have promoted actively the governance behaviors of minority shareholders, especially with the attentions increased, minority shareholders tend to adopt active governance (voting by hand) for participation, which discovers that minority shareholders have not kept indifferent on the corporate governance in the new internet background, the result discloses new participants and governance ways to perfect the corporate governance mechanism.

Therefore, the securities regulatory authorities should regard minority shareholders from a new perspective, and create convenient conditions for their online voting or securities trading from policy-making. In addition, listed companies should re-examine the roles of supervision and governance of minority shareholders and create ideal governance environments for them through improving the board governance mechanism.

\section{REFERENCES}

[1] Liu Shaobo, Mao Chao, Control over Managers' Idiosyncrasy and Fund Transfer of Majority shareholders [J]. Economic Research Journal, 2016(04):129-145.

[2] Wang K, Xiao X. Controlling shareholders' tunneling and executive compensation: Evidence from China[J]. Journal of Accounting and Public Policy, 2011,30(1):89-100.

[3] Xie Shifei, Studies on Building Systems and Mechanism Against Boom and Slump of Stock Market in China [M]. Southwest China Normal University Press, 2015.

[4] Hart S J G A. Takeover Bids, the Free-Rider Problem, and the Theory of the Corporate[J]. The Bell Journal of Economics, 1980,11(1):42-64.

[5] Vishny A S A R. Large Shareholders and Corporate Control[J]. Econom, Journal Of Political, 1986,94(3):461-488.

[6] Li Qian, Wu Hao, Studies on Tendencies of Investors' Behaviors under Big Data Background: From the Perspective of "Connotation-ThoughtMethod" [J]. Journal of Central University of Finance \& Economics, 2017(02):52-62.

[7] $\mathrm{Li}$ Weian, Changes of Corporate Governance at the Era of Mobile Internet [J]. Nankai Business Review, 2014(04):1.

[8] Bebchuk L A. The Case for Increasing Shareholder Power[J]. Harvard Law Review, 2005,118(3):833-914.

[9] Chen Z K B Y Z. Does granting minority shareholders direct control over corporate decisions help reduce value decreasing corporate decisions in firms with concentrated share ownership? A natural experiment from China[J]. The Accounting Review, 2010,88:1211-1238.

[10] Zheng Xiutian, Xu Yongbin, Behavior Selection for Minority Shareholders Facing Majority shareholders Seizing Private Benefits-Rational Indifference or Active Supervision? [J]. Economic Review, 2013(06):11-16
[11] Kong Dongmin, Liu Shasha, Li Wenjing, et al, Is indifference rational? Participation of Minority Shareholders in Corporate Governance and Investors Protection [J]. China Economic Quarterly, 2013(01):1-28.

[12] Jia Yingdan, Corporate Governance Effect Disputed by Minority Shareholders--Proofs from Auditors Re-appointment Proposal [J]. Auditing Research, 2015(01):99-105.

[13] Xu Xiangyi, Bian Jiang, Studies on Protection Mechanism of Rights and Interests of Minority Shareholders in Corporate Governance [J]. China Industrial Economics, 2004(09):65-71.

[14] Zhang Weiwei, Protection of Rights and Interests of Minority Shareholders in the Internet Environment--Based on analysis of minority shareholders denying debt to equity plan at Wuguo B [J]. Finance \& Accounting, 2015(07):32-34.

[15] Li Wenjing, Kong Dongmin, Liu Shasha, et al, Can minority shareholder take a free rid only? Proofs from online voting by social shareholders at SZSE [J]. Journal of Financial Research, 2012(03):152165 .

[16] Li Wenjing, Kong Dongmin, Information Transparency, Corporate Governance and Participation by Minority Shareholders [J]. Accounting Research, 2013(01):42-49.

[17] Wang Wei, Ye Jianhong, No Voting by Investors: Is information asymmetric or not related to benefits? [J]. Journal of Zhejiang University(Humanities and Social Sciences), 2015(03):68-83.

[18] Listokin Y. If You Give Shareholders Power, Do They Use It? An Empirical Analysis[J]. Journal of Institutional and Theoretical Economics, 2010,166(1):38-53.

[19] Zhang Jide, Liao Wei, Zhang Rongwu, Influence of Common Investors' Attentions on Volume and Prices in Stock Business--Based on empirical research of Baidu index [J]. Accounting Research, 2014(08):52-59.

[20] Yung K, Nafar N. Investor attention and the expected returns of reits[J]. International Review of Economics \& Finance, 2017,48:423-439.

[21] DRAKE M S, ROULSTONE D T, THORNOCK J R. Investor Information Demand: Evidence from Google Searches Around Earnings Announcements[J]. Journal of Accounting Research, 2012(4):10011040.

[22] Schroff S, Meyer S, Burghof H. Retail investor information demandspeculating and investing in structured products[J]. The European Journal of Finance, 2016,22(11):1063-1085.

[23] Shen Yifeng, Yang Jing, Li Peigong, Studies on Influence of Online Consensus on Corporate Governance Mechanism---based on experimental evidence of private placement [J]. Nankai Business Review, 2013(03):80-88.

[24] Li Weian, Online Governance Promoting the Rebuilding of Governance Flow [J]. Nankai Business Review, 2014(06):1.

[25] Xia Donglin, Qian Ping, Analysis of Free Ride and Shareholders Behaviors in Corporate Governance Structure [J]. Economic Science, 2000(04):14-20.

[26] Yang Jing, Shen Yifeng, Xiong Yan, Private Investors' Positivism and Corporate Cash Dividend Policy--from the Perspective of Attentions by Public Media [J]. Journal of Xiamen University(Arts \& Social Sciences) 2017(02):106-117.

[27] Xing Tiancai, Zong Jichuan, Studies on Shareholders' Voting Behaviors for Listed Companies in China--based on empirical analysis of reform of non-tradable shares and classified voting [J]. Finance Forum, 2009(07):45-51.

[28] Da Z, Engelberg J G P. In Search of Attention[J]. The Journal of Finance, 2011,66(5):1461-1499.

[29] Kong Dongmin, Liu Shasha, Ying Qianwei, Roles of Media in Corporate Behaviors: Doing good or Doing bad? [J]. Management World, 2013(07):145-162.

[30] Wang Yong, Yang Qingyun, Influence of Online Attentions on Stock Earnings in China--based on empirical study of Huxu attention [J]. Reviews of Investment Studies, 2014(02):143-149.

[31] Wu Dejun, Corporate Governance, Media Attentions and Corporate Social Responsibilities [J]. Journal of Zhongnan University of Economics and Law, 2016(05):110-117. 